\section{THE POST-COLONIAL STATE AND ECONOMIC AND POLITICAL REFORMS IN CAMEROON}

\author{
Piet Konings
}

Until recently Cameroon was lauded by many observers, including World Bank staff, as one of the most prosperous and most stable countries in subSaharan Africa. Today, this rosy assessment has been replaced by gloom. The country is facing an unprecedented economic and political crisis. After some initial hesitation, the Cameroonian government could not escape during the deteriorating economic situation from calling upon the International Monetary Fund (IMF) and World Bank for the implementation of a Structural Adjustment Programme (SAP). It was soon required to conform to the new standards of these financial institutions, linking structural adjustment to democratization. So, in addition to the economic conditionality that plagued African states during much of the 1980 s, it was also obliged to accept 'political conditionality'.

The IMF and World Bank are, in fact, the spearheads of the neoliberal project that has become the hegemonic ideological project of our time following the collapse of the socialist-oriented states in Eastern Europe. The major tenets of 'neoliberalism' are: (a) the belief that rolling the state back and liberalizing the economy will induce economic development, and (b) the belief that there is an intrinsic connection between capitalism and democracy. Democracy is thought to enhance the prospects for economic development, while economic liberalization is thought to enhance the prospects for democracy (Beckman 1993: 20-33; Jeffries 1993: 20-35; Mkandawire 1994: 155-73). Recent World Bank reports signal a major shift in the Western donors' perspectives, from a preference for technocraticauthoritarian regimes to an endorsement of democratic government. Democracy is said to be capable of legitimizing the imperatives of adjustment. It can also improve governance and state capacity to implement the austere adjustment measures. These reports, however, stress that sustainable democracy cannot be achieved without the empowerment of civil society.
Like elsewhere in the world, the SAP imposed upon Cameroon by the Like elsewhere IMF and the World Bank has involved the application of a standard package of measures to stabilize the domestic economy, to minimalize state intervention in the economy, and to give the market a freer hand in the allocation of resources. These measures include reduction of public expenditure, removal resources. These measures inction and promoof public subsidies, dismantlement of public sector, privatization and promotion of private enterprise (both national and foreign), trade liberalization, tion of private entions, and producer price reforms, devaluation, restructuring of state institing is beyond legal reforms aimed at supplying an enabling environment. It is beyond dispute that the SAP has yielded some results in Cameroon: the labour and investment codes have been liberalized, several price controls have been investment codes have and export duties have been reduced, the commerabolished, many import and exper liberalized by withdrawing the buying cialization of export crops has been liberalized by withdrawing the buying monopoly of the cooperatives, restricting the activities of the National Produce Marketing Board to quality control, and allying local to world Produce Marke Communauté Financière Africaine (CFA) market prices, and, of late, the Communaute Financiere Africaine (CFA) franc has been drastically devalued. What is most striking in the Cameroonian situation, however, is that most of these results in economic libe

have been accomplished only after initial government opposition. There is, in fact, ample evidence to demonstrate that the Cameroonian government has constantly attempted to undermine the economic and political reforms advocated by the Western donors and international financial tical reforms advocated by the Wester slow institutions. As a result, the process of economic liberalization has been slow and inconsistent. The necessary institutional reform in the public and parastatal sectors, for example, has been largely thwarted by government delaying tactics and half-hearted implementation. This is particularly grave as the a cornerstone of the SAP. Political liberalization has hardly gone beyond the a cornerstone of the SAP introduction of a multi-party system and a larger measure of press freedom 4 The government's weak commitment and limited implementation has led tc protracted conflicts with the Western donors and international

institutions, sometimes followed by suspension of financial aid. It will be argued in this chapter that the government's persistent opposition to the neoliberal economic and political reforms can be explained by the class character of the Cameroonian post-colonial state. In his semina the class character of book on Cameroonian politics, Bayart Ahidjo, was instrumental in creating: highly centralized, authoritarian and patrimonial state and in shaping : he various élite groups in society which wer. hegemonic alliance out of the various elice gen given access to state resources and rent-seeking activities so as to cem in their loyalty to him. This hegemonic alliance has a vested interest in thi status quo and is inclined to resist any economic and political liberalization measures which threaten its control over state resources and rent-seekin: activities. Apparently, its resistance has been successful: none of the reform 


\section{PIET KONINGS}

implemented so far seems to have struck at the roots of the authoritarian and patrimonial state as yet.

It will be shown in this chapter that one of the reasons for this success has been the regime's proficiency in the game of token implementation of economic and political reforms. Another is its proven ability to play donors off against one another so that conditionality has remained largely illusory. This was facilitated by the fact that the major Western donors and international financial institutions have continuously displayed a rather ambivalent and inconsistent attitude towards the regime. While they have sometimes blamed and 'punished' the regime for its lack of implementation of economic and political reforms, they have nevertheless continued to side with the regime against the opposition and to provide it with financial aid, for mainly economic and political reasons. The IMF and World Bank have never accepted the opposition parties in Cameroon as equal discussion parties, as they feared that any recognition of the opposition might have a negative impact on its established cooperation with the ruling regime needed for the implementation of the SAP. Moreover, the opposition's initial boycott of the economy, its fragmentation and its apparent incapacity to present a clear alternative to the ruling regime contributed to their decision to negotiate with the ruling regime exclusively. Given its enormous economic interests in its previous Trusteeship territory, it is not surprising that France has been even less inclined than other Western donor countries to insist on the strict implementation of the neoliberal project.

\section{THE NATURE OF THE POST-COLONIAL STATE}

\section{IN CAMEROON}

From the very start, the Federal State of Cameroon which came into being in 1961 following the achievement of independence and reunification of the previous French and British trusteeship territories, faced enormous problems (Le Vine 1964, 1971; Johnson 1970; Bayart 1979). There was the problem of underdevelopment and dependency. The economy was largely dependent on the export of a few agricultural products - in order of value: cocoa, coffee, bananas and palm oil. The tiny industrial sector, dominated by French capital, was mainly involved in the transformation of agricultural produce for export (Hugon 1968). France's predominant role in the national economy was clearly indicated by import-export statistics. In 1961 it accounted for 59 per cent of Cameroonian exports and 55 per cent of its imports. Membership in the CFA Franc Zone tied Cameroon monetarily to France; moreover, while it had the advantage of promoting economic stability and allowing an open trade regime, it established a tendency towards overvaluation of the currency and encouraged the development of imported consumer tastes (Vallée 1989). Through the various agreements of cooperation signed by France and Cameroon before independence,
CAMEROON'S POST-COLONIAL STATE REFORMS

France remained in a position to influence Cameroon's domestic and foreign policy strongly.

There was also the problem of ethnic fragmentation and regional divisions exacerbated by a colonial history that had split the country into English-speaking and French-speaking groups. And, last but not least, a civil war was going on at the time of independence and reunification, particularly in the Bassa and Bamilike areas. This bloody and destructive battle was the direct consequence of the determined effort of the Cameroonian government and the French to suppress the radical nationalist party, the Union des Populations du Cameroun (UPC) (Joseph 1977).

The challenge of solving these problems devolved on Ahmadou Ahidjo, the first President of the federal state. He was a Muslim and a Fulbe, the dominant ethnic group in Northern Cameroon (Azarya 1978). Initially, he was considered by many to be a mere puppet of the French and an intermediary figure at most. Indeed, he owned his ascendancy to power to a large extent to the French and he enjoyed hardly any support in the southern part of the country which had been more subject to colonial capitalism, education and Christianity than the north (Bayart 1979). Soon, however, Ahidjo displayed an unexpected political craftmanship which enabled him to strengthen his originally weak position and eventually to construct a system of personal rule. Centralization, coalition-building and repression were his major strategies to concentrate political and economic power in his office and person (DeLancey 1989).

The first strategy, centralization, had numerous aspects. There was the concentration of administrative decision-making in the capital, Yaoundé, and the use of the Constitution to funnel authority to the President. There was the formation of a single party, the Cameroon National Union (CNU), which was completed in 1966 after a two-step process of forging a single party in the francophone area and then merging this with the remaining parties of the anglophone area. As Bayart (1979: 163) has shown, the party was firmly subordinated to the state, an arm of the government and particularly of the President: 'it is the party that emanates from the person of $\mathrm{Mr}$ Ahidjo, not the other way round'. There was also the dissolution of the federation in 1972 to form a unitary system of government. Centralization was enhanced by the elimination of autonomous forms of organization. Previously independent organizations became subordinated to the political party through the party's women's, youth and labour wings or through domination by or incorporation into government agencies (as had occurred with the anglophone cooperative movement). Related to this were policies to destroy any limited autonomy enjoyed either by local governments (more a reality in anglophone Cameroon) or by traditional governments.

The second strategy was coalition-building. In his study of the Cameroonian post-colonial state, Bayart (1979) highlights Ahidjo's pursuit of building a 'hegemonic alliance' out of different élite groups on the national 
and regional levels. This hegemonic alliance comprised not only of politicians, bureaucrats and businessmen but equally the traditional élite, the chiefs. From this heterogeneous coalition, a new dominant class was slowly emerging around the state. Ngayap (1983) asserted that the ruling class in Cameroon consisted of approximately 1,000 people. But if Bayart's contention that the traditional élite has also been co-opted into this alliance is valid, I would submit that this number is rather conservative. This hegemonic alliance was pulled together by several means, including the development of an extensive patron-client system. Clients were supposed to owe total allegiance to Ahidjo. Attempts by any of them to build a power base of their own was construed as betrayal that sanctioned removal from office. Ahidjo selected his clients on the basis of ethnic arithmetic or ethnic balancing. He was conscious that representation in the cabinet, national assembly, and so on, would reflect the various ethnic groups in society. As a matter of fact, the government's hand-picked élite or barons served as transmission belts between the President and the different ethnic groups. Thus every important ethnic group felt represented within the regime and thus able to exercise some influence on government policy (Jua 1991: 16270; van de Walle 1990).

Loyal followers in the ethno-client network were rewarded by appointments and nominations to state offices, access to state resources, and rentseeking opportunities. Beyond the numerous appointments Ahidjo could make to the cabinet and elsewhere in the system, he had a variety of other techniques to allow individuals to profit, even though they might not receive a lucrative appointment. For some associates of the President there were special loans from the banks, loans without interest or any expectation of repayment. Overall, the existence of smuggling and corruption provided a major avenue for the President to allow supporters to receive rewards. Special efforts were also made to appease and maintain support among the civil servants or bureaucrats. They received excellent pay compared to the average income of the Cameroonian citizens, as well as numerous perks such as free housing. Despite these advantages, they were allowed to convert their posts into monopoly rent-seeking opportunities. They considered the state to be a resource base, from where they could explore various pathways of capital accumulation (Geschiere and Konings 1993). The expansion of the state, particularly into the economic arena, was promoted to manipulate and sustain the alliance. It would be wrong to argue that rentseeking and patronage were the only reasons the state promoted state expansion after independence. Extensive public ownership conformed to prevailing development doctrines, was warmly supported by the donors, and responded to real development needs. Still, the scope that state ownership was to achieve (by 1988, the state had more than 150 parastatals in its portfolio) was helped by the fact that it afforded leaders like Ahidjo positions of prestige and power to distribute. In the context of the patrimonial state, these parastatals were converted into prebends for Directors-General or to serve other exclusive interests of the hegemonic class (Joseph 1978). Given this penchant of the parastatals to promote political rather than economic goals, it is not astonishing at all that, for the most part, they performed inefficiently. Their dependence upon the state for subsidies became a permanent rather than transient feature. This furthered ischaemia at the state treasury; by 1988 , annual parastatal subsidies amounted to about FCFA 150 billion (van de Walle 1990; Konings 1993).

While Ahidjo constantly emphasized the need for ethnic balance and national unity, there is nevertheless sufficient evidence that two ethnic élite groups enjoyed a privileged position in opportunities for capital accumulation. These were, first of all, the Muslim Fulbe élite, especially those originating from Garoua, the home town of Ahidjo, the so-called 'Garoua barons'. And second, the Bamilike élite, renowned in Cameroon for their 'spirit of capitalism' (Warnier 1993). The Bamilike territory was until about 1970 one of the most important areas of UPC resistance against the regime. It is widely believed in Cameroon that Ahidjo was ready to grant the Bamilike élite ample room for capital accumulation, on condition that they would not meddle in politics. Ultimately, in spite of the variety of incentives for cooperation and agreement used by Ahidjo, the stability of the regime was based on the widespread use of repression and the suppression of human rights.

Ahidjo did not only succeed in gradually and imperceptively stabilizing his regime, he was even able to achieve a certain degree of autonomy from the French. Over the years, Ahidjo has developed relations with trading partners other than France. In 1985, France accounted for only 35 per cent of Cameroonian exports and 44 per cent of its imports. The regime's apparent political stability, its lack of ideological posturing and its liberal investment code appealed to the Western donors and business milieux. With an annual growth rate of some 8 per cent from 1970 to 1985 , the Cameroonian economy was long considered one of the success stories in b-Saharan Africa. While not without foundation, this view of the coun-

7's economy has proved to be excessively optimistic as it failed to take ote of several disturbing trends by the end of Ahidjo's tenure. Much of the hitry's success was based on its rich resource base, yet the agricultural for was stagnating: the growth registered was due mostly to increased reage under cultivation brought about by expensive government and hor programmes, and it disguised the absence of sustained productivity nowth. Moreover, infrastructural problems were daunting. The most disthing trend, however, was the rapid growth of a costly and ineffectual iblic sector, though quite understandable from political efficiency conterations. Cameroon's seemingly impressive growth rate until 1986 was fated by the discovery of oil in 1977. Strikingly, oil output and oil tenues have remained a state secret under Ahidjo's administration. 


\section{PIET KONINGS}

Apparently, the bulk of oil revenues has been placed in foreign banks as extra-budgetary accounts. The official justification given by Ahidjo for this strategy was the elimination of the boom mentality that had crippled agricultural production in other African countries following the discovery of oil. Nevertheless, in conformity with the regime's patrimonial logic, the primary function of these extra-budgetary accounts soon became to cover parastatal deficits (van de Walle 1990; Jua 1991: 162-70).

Ahidjo stunned the Cameroonian population on 4 November 1982 by announcing that he was resigning as President of the country and turning his office over to his constitutionally designated successor, the Prime Minister, Paul Biya; the transfer to take effect on 6 November 1982. Unlike Ahidjo, Biya was a Christian from the southern part of francophone $\mathrm{Ca}$ meroon. He belonged to an ethnic group which is loosely classified as Beti. Although there were promising signs of change at the start of the Biya regime, it soon turned out that in all essential respects Ahidjo's system was continued under Biya's leadership. Soon after his assumption of power, Biya promised a New Deal. He spoke of a certain liberalization of the political system, an internal democratization of the single party, and the need of 'rigour, integrity and moralization', thus challenging the autocratic and patrimonial state (Takougang 1993: 91-101). At first, many Cameroonians were sceptical. Biya was a product of his predecessor, Ahmadou Ahidjo, and owed his political fortunes to him. Moreover, although Ahidjo had resigned as the Head of State, he still retained the powerful office of chairman of the only party in the country, the CNU. Despite the initial scepticism, Biya's many speeches following his accession to power helped to convince many Cameroonians that he was serious about instituting change. This conviction was strengthened by a certain relaxation of police state controls in 1983 .

Whether the concept of New Deal was simple a public relations ploy to extricate himself from Ahidjo's shadow, as some now argue, or whether it was a genuine attempt to forge a new direction for the country, the implementation of economic and political reforms would be extremely difficult within the existing political system. Ahidjo had spent more than two decades as Head of State and, during that tenure, had filled most of the top party and government positions with loyalists or people who believed in his political philosophy. Many in the government and the business community, especially the Muslim Fulbe, were not only unwilling to accept the fact that Ahidjo had handed over power to a southern Christian, but also perceived Biya's call for rigour, integrity and moralization as an effort to deprive them of the rights and privileges they had long enjoyed under Ahidjo's administration. Adding to the difficult situation Biya faced, was the fact that the former President continued to play a highly visible role in national politics until 1983-4, when he was accused of being involved in an assassination attempt on Biya (Bandolo 1985).
CAMEROON'S POST-COLONIAL STATE REFORMS

Therefore, in order to implement his New Deal programme, Biya had to replace these men with people who were loyal to him and committed to reform. However, it soon became apparent that he was either unwilling or simply lacked the resolute, tough and uncompromising leadership of his predecessor to do so. For one thing, any immediate wholesale replacement of experienced, albeit reactionary officials in the upper echelon of the government might have seriously impeded the smooth running of the administration. Moreover, many of the men in these positions were colleagues with whom Biya had served in government and who, like him, owed their political fortunes to Ahidjo. Consequently, even though some of them did not believe in his New Deal, he did not immediately replace them. Certain well-known 'barons' of Ahidjo were forced to resign, but within a few years they were back in prominent positions again, often as heads of parastatals. After an attempted coup d'état by the Republican Guard, which was still mainly composed of Ahidjo loyalists, on 6 April 1984, the police state was reimposed in full, with censorship, secretive government and a powerful secret police.

Given that his hold on power had become even more precarious after this failed coup d'état, Biya was compelled to raise the costs of maintaining the loose ruling alliance. He needed to please the state apparatus, notably those parts of the army which had supported him during the coup d'état attempt, and he wanted to meet the heightened expectations of his fellow Beti. A direct consequence was the acceleration of budgetary and state employment growth. The Beti élite saw the transfer of power from Ahidjo to Biya simply as an opportunity to, in Bayart's words (1989), promote ethnofascism. By implication, therefore, the fact that the President hailed from a specific ethnic group, should automatically give his ethnic fellowmen the right to monopolize power. Encountering great difficulties in consolidating his power, Biya started to give in to these ethnic pressures and to co-opt the Beti élite in the ruling alliance. The northern and Bamilike businessmen who had enjoyed a privileged position during Ahidjo's administration were increasingly replaced by Beti businessmen, the so-called Beti Mafia. Out of protest against their discrimination, Bamilike businessmen withdrew their savings from the banks and transferred them to informal saving circuits called tontines (Henry et al. 1991). This contributed to the growing liquidity problems of the banks. The Biya regime increased the number of civil servants from about 80,000 in 1982 to about 180,000 in 1988; the majority of the new employees being recruited among the Beti. The Beti also increasingly monopolized the pivotal positions in the government and security organs. Takougang (1993: 95-6) reports that as of August 1991, thirty-seven of the forty-seven senior prefects (heads of administrative divisions), three-quarters of the directors and general managers of the parastatal corporations in the country, and twenty-two of the thirty-eight high-ranking bureaucrats who had been appointed in the newly created 
office of the Prime Minister, were from the President's ethnic group. The new regime's barons appeared to be much bolder in staking out claims on the state's resources than Ahidjo's supporters had been. Corruption and rent-seeking had always been fundamental characteristics of the regime (Joseph 1978; Médard 1977); after 1984 they increased to the point of becoming dysfunctional. When this political conjuncture was combined with a severe exogenous economic shock, the system started to crumble.

\section{THE POST-COLONIAL STATE AND \\ STRUCTURAL ADJUSTMENT}

From the mid-1980s the post-colonial state was confronted with a severe economic crisis (Korner 1988: 77-94; van de Walle 1990). This crisis posed a severe threat to the economic base of the patrimonial state as well as to the system of prerogatives and privilege of the hegemonic alliance. A sharp downfall in commodity prices and the slide in the value of the American dollar against the CFA franc resulted in a 70 per cent deterioration in the country's terms of trade during the period 1986-93. The state's oil revenues, for example, decreased from US\$350 million in 1985 to US\$207 in 1988. The crisis was aggravated by massive capital flight estimated at FCFA150 billion a year which was almost a quarter of the annual national budget. The free flow of currency between the CFA Franc Zone and France encouraged the Cameroonian élite to transfer their capital to French banks which, moreover, supplied higher interest rates than the Cameroonian banks. As a result of the crisis, several government projects proposed or started in the boom days of the New Deal were either suspended or abandoned because of severe financial constraints. The deteriorating economic situation also forced many foreign companies that had invested in Cameroon to leave the country, further exacerbating the employment situation. The regime also experienced great difficulties in paying cash-crop farmers. Cocoa and coffee farmers responded by switching from cash-crop production to food-crop production.

The government's initial response to the trade shock of the mid-1980s was to rely on external financing in the hope of favourable commodity prices or exchange rate changes. As a result, external debt rose from US\$2.7 billion in 1984 to US\$4.7 billion in 1989. The IMF and the World Bank had been negotiating with the government on and off since mid-1986, without reaching agreement. At this time, Biya staked the national prestige on refusing the tough austerity programmes of those two institutions. Through 1986 and 1987, he insisted that Cameroon would undertake an adjustment of its own, and seek only non-conditional capital from bilateral donors and the private banks. He announced a cut of several hundred billion CFA in the 1987 fiscal year budget, a hiring freeze, new taxes on luxury goods and, in late 1987, the creation of a new anti-crisis ministry, the Ministry for the Stabilization of Public Funds.
Notwithstanding Biya's tough rhetoric, the crisis continued to worsen, with expenditure overruns of FCFA450 billion in 1986-7 (out of a total budget of FCFA 800 billion) and of FCFA150 billion in the next fiscal year. Recourse to the international institutions became inevitable. Agreement was reached with the IMF on a stabilization plan in September 1988 and with the World Bank on a structural adjustment loan in May 1989. The World Bank and IMF adjustment strategies have contained the conventional prescriptions of important cuts in public expenditures, increased state revenues and the compression of consumption, coupled with the promotion of selective investments to foster long-term growth. They have called for the privatization, rehabilitation or elimination of almost all of the nation's parastatals, as well as thoroughgoing liberalization (van de Walle 1990).

Given the nature of the Cameroonian post-colonial state and the vested interests of the state élites in the status quo, it is not surprising that the Biya regime's implementation of the adjustment policies tended to be halfhearted and erratic. As van de Walle (1990: 54) perceptively observes, 'it has attempted to cut off some fat, to excise some of its patrimonial tendencies while maintaining its core logic'. It had little choice but to cut public expenditures, since state coffers were empty, but personnel expenditures were initially left untouched. To take one example, only 5 per cent of the Ministry of Agriculture's total budget of FCFA39 billion was set aside in the 1988-9 budget for non-personnel related expenditures. The absurdity of this approach from a developmental point of view is well compensated by the political logic of placating the administration. Despite his constant exhortations against corruption, Biya continued to distribute rents so as to regulate and dominate the different factions of the hegemonic alliance. He also attempted to delay the reform of the costly and inefficient public and parastatal sector, which was a cornerstone of the World Bank's adjustment programme. In May 1987, he appeared to side with the World Bank when he appointed a National Commission to review the performance of the parastatal sector (Tedga 1990), but, subsequently, he took no action on the Commission's report. It was only under constant pressure from the World Bank that he started to restructure the parastatal sector. In the end five parastatals were privatized, forty-four were liquidated, and the remaining 104 were required to sign 'performance contracts' with the government in 1989-90 which aimed at their self-sufficiency and eventual profitability. These performance contracts often gave rise to severe cuts in workers' wages and fringe benefits as well as mass lay-offs (Konings 1993)

Cameroon's IMF standby agreement programmes, signed in September 1988 and December 1991, expired without having fully disbursed authorized funds and without a follow-on programme in place, due to the Biya government's failure to comply with programme conditionality. In September 1992, IMF programming, World Bank project assistance, and Paris Club debt relief was suspended because of accumulating debt arrears. It was its 
continuing friendly ties with France that saved the regime from the disastrous consequences of falling into the status of non-accrual, which would have destroyed the country's financial credibility throughout the world: France was ready to pay Cameroon's accumulated debt arrears with the World Bank, amounting to FCFA60 billion. The important role of France in Cameroon's structural adjustment programme is manifest in its financial aid to Cameroon during the period 1990-2: this totalled FCFA181 billion, representing 36 per cent of all aid.

For a long time, the Biya regime strongly refused to give in to the World Bank's demand of laying off about 40,000 civil servants and state agents, the more so as most of them were Beti. It was, however, ready to reduce personnel costs. In 1991 it announced further cuts in the salaries and benefits of government employees. For instance, there was a 50 per cent cut in out-of-station and other allowances that civil servants could receive and a 7 per cent pay cut for most government workers. It also eliminated free housing, except to very high-ranking government officials such as ministers, directors and secretary-generals. The government, however, experienced increasing difficulties in paying its civil servants. Rather than laying off a certain proportion of the 'overdeveloped' civil service, it decided to implement two draconian salary reductions of respectively 30 per cent in January 1993 and 50 per cent in November 1993. Remarkably, in October 1993 France agreed to allocate a loan of FCFA15 billion to Cameroon to help the government in coming to terms with the salary arrears owed to civil servants.

France and Cameroon used to resist any pressures of the IMF and the World Bank to agree upon a devaluation of the currency in the CFA Franc Zone. In January 1994, however, they consented to a 50 per cent devaluation of the CFA franc. In return, the IMF ratified a standby credit of US\$114 million to Cameroon on 15 May 1994 so as to support the government's economic policies for the next eighteen months. The disbursement of this loan was made conditional upon the government's termination of the contracts of 20,000 civil servants. The devaluation seems to have had a positive effect on the production and exports of cash crops, especially cocoa, coffee, and cotton (Pelzer 1994: 205-15).

In 1990 van de Walle concluded as follows about the politics of structural adjustment in Cameroon:

The inconsistent pace of reforms, its recurring breakdowns and betrayals suggest Biya is manoeuvering to placate the country's creditor while gingerly testing the political limits of the reform process. Ambiguity is an asset for Biya, as it keeps potential foyers of opposition off guard while cuts are made surreptitiously. Donor pressure and threats can be used to maintain pressure on recalcitrant allies. Still, Machiavellian machinations explain only a part of the reform's uneven progress. Some of the manoeuvering may be little more than delaying tactics: time may after all solve some of the problems while a rebound in world commodity prices could defer the crisis at least temporarily. (van de Walle 1990: 70-1)

This conclusion seems still to be largely valid in 1994. In its political manoeuvring and delaying tactics the Biya regime has continued to be supported by France. One of the reasons for France's persistent support seems to be the concentration of organized opposition in Cameroon around a 'hard' anglophone core. Another reason seems to be the strong belief in French government circles that the shadow of Washington is behind the IMF, the World Bank and the Cameroonian opposition.

\section{THE POST-COLONIAL STATE AND DEMOCRATIZATION}

By 1990 one could observe widespread popular discontent within the Cameroonian urban areas with the regime in power and growing dissent within the hegemonic alliance. Various internal and external factors are responsible for this situation. The majority of the population held the corrupt, authoritarian regime responsible for the serious economic crisis, resulting in its loss of legitimacy. Moreover, straight after his ascendancy to power, Biya had started to project himself as an advocate of greater political freedom and democratic reforms. He, however, believed that both should occur, at least in the short term, under the auspices of the single party which had been rebaptized Cameroon People's Democratic Movement (CPDM) in 1985. In other words, the party was supposed to define the extent to which freedom and democracy were going to be allowed in the country. Nevertheless, his limited political reforms encouraged the people, waking up after years of submission, to demand more political freedom and democracy than the Biya regime was willing to grant. The traditional propaganda, equating a single party with peace and harmony and a plural system with strife and discord, fell on increasingly deaf ears. In addition, with the end of the Cold War and the move towards democratization in Eastern Europe, Cameroonians, like Africans elsewhere on the continent, looked upon these changes as an added incentive to demand greater political reforms, including the introduction of multiparty democracy. Some of the élite, particularly those who had become dissatisfied with the regime because of its promotion of Beti domination, began to give expression to general discontent and even tried to organize the urban masses into political parties. They were joined by some members of the middle class who had become increasingly critical of the authoritarian and patrimonial state, such as members of the Cameroon Bar Association, intellectuals and journalists. Their critical attacks and organizational efforts, however, met first severe 
repression on the part of the state which wanted to keep the democratization process under control.

On 19 February 1990, ten prominent Cameroonians in Douala were arrested and charged with organizing secret meetings with the aim of undermining state authority and forming an alternative party. The leader of the group, Yondo Black, a renowned lawyer, received a three-year sentence from a military tribunal. Before and after his condemnation there were massive protest demonstrations. Following this event, the call for democracy and multipartyism became louder and louder. In reply, the government staged anti-democratization marches throughout the national territory in which participants shouted slogans like 'No to Precipitate Democratization'. On 9 April 1990, Biya said calls for a multiparty system were manoeuvres for diversion, intoxication and destabilization. In Bamen$\mathrm{da}$, the capital of the North West Province in anglophone Cameroon, a new party, the so-called Social Democratic Front (SDF), had been founded by then and, according to its leader John Fru Ndi, had given details of its formation to the authorities on $16 \mathrm{March} 1990$. When no reply was received, the SDF organized a huge rally at Bamenda on 26 May 1990, at which police opened fire, killing six people.

During the following weeks there was a remarkable change in President Biya's attitude towards the growing demand for multipartyism. In a nationwide address in early June 1990, he claimed that Cameroonians had nothing to learn from abroad with regard to democracy. He himself had initiated perestroika and glasnost in his country long before Gorbachev did in the Soviet Union. However, during the CPDM Congress that took place at Yaoundé a few weeks later, he surrendered to the multiparty system demand. On that occasion, he declared that the party must be ready to face competition and added: 'Consider also that other schools of thought exist which must be taken into account, fought against or integrated' (Derrick 1992: 172)

What happened in those weeks? Even though that was the very time that Cameroonians were absorbed in the good showing of their national soccer team during the World Cup competition in Italy, and seemed to think of nothing but football, in fact decisive pressure was brought to bear during these weeks. There was the pastoral letter from the Catholic bishops at Whitsun, which attributed the economic and political crisis mainly to the egoism, corruption and authoritarianism of the state élites, and called for an end to single-party rule. There was the resignation of John Ngu Foncha, the former Prime Minister of anglophone Cameroon who had led it into the federation in 1961, as an honorary Vice-Chairman of the CPDM. Foncha condemned the shooting and expressed the demand being made by anglophone Cameroonians for a return to a federal system. There was the pressure from the IMF and World Bank as well as from other international aid organizations. Financial assistance and loans were suspended, leaving the Cameroonian government with hardly any alternative but to open up grudgingly to the opposition. There was also pressure from France, which a regime so close to France for thirty years could not ignore. At the Sixteenth Summit of France and African States, held on 20-21 June 1990 at La Baule in France, the declaration agreed on by those attending, including Biya, spoke of 'the need to associate the relevant population more closely with the construction of their political, social and economic future'. François Mitterrand, speaking for himself, went further and said French aid would be 'less enthusiastic to regimes which behave in an authoritarian fashion and fail to accept the move towards democracy' (Derrick 1992: 172).

After the surrender in principle, months passed before a new law was passed by the National Assembly on 5 December 1990, formally allowing creation of several parties on certain conditions. But, in the meantime, there was relaxation in many other ways. Many demonstrations and meetings were held in the Cameroonian cities. They expressed the new-found freedom and pent-up feelings about decades without freedom. Similarly, a free press blossomed, until after a few months, there were about sixty newspapers in circulation, including about fifteen dailies. The government did not take all this unrestrained freedom and met it with repression, but fitful repression that failed to check it. So as soon as new parties were formed, hundreds of thousands of people were waiting to rush to join them.

In the first months of 1991 new parties received their registration. The major new parties were:

- The Social Democratic Front (SDF). This was originally largely an anglophone party, but it was capable of gradually extending its membership to the francophone area, notably to the neighbouring francophone provinces. For example it enjoyed great support among the Bamilike in the West Province, an ethnic group that was closely related to the people in the Bamenda area, the craddle of the SDF. The party's Chairman was John Fru Ndi, a librarian by profession, who had failed to win a seat in the National Assembly on a CPDM ticket during the 1988 elections. $\mathrm{He}$ soon achieved an immense popularity among the urban masses because of his great courage and populist style of leadership.

- The Union des Populations du Cameroun (UPC). This radical preindependence party which had been suppressed by the French and Ahidjo government, was refounded and was capable of rewinning strong support in its original areas of operation, Douala, the economic capital, and the Bamilike-Bassa regions. Its leadership consisted partly of exCPDM leaders and partly of old UPC leaders who had returned from exile. The party was soon marked by internal divisions based on personal, ideological and ethnic considerations.

- The Union Nationale pour la Démocratie et le Progrès (UNDP). This party enjoyed most support among the Fulbe of Northern Cameroon, 
PIET KONINGS

Ahidjo's ethnic group. Its leadership had held prominent positions in the party and the government during the Ahidjo period and early Biya period. It claimed the Ahidjo heritage.

These three parties were the main contenders with the CPDM by mid1990. Many other parties were authorized, making a total of no less than forty-eight (with about twenty others operating but not legally registered) by early 1992. The legalization of many small parties was suspected in Cameroon to be intended to split the opposition to the government party. Strikingly, none of the parties had worked out a well-defined programme, except maybe the SDF. Most of them did not go beyond generally calling for better social justice, cleaning up of public life, an end to secretive government, and measures to restore the economic situation. In this respect, it is worthwhile to mention that nearly all of them supported the implementation of the SAP in Cameroon. Apparently, their main concern was to devise strategies for the seizure of power from the ruling CPDM government. Like the ruling party, they usually tried to recruit their members through the creation of an ethno-client network (Schilder 1993: 115-22). Of course, the charisma of the leadership, too, tended to be an important asset in the expansion of their membership.

The formation of the new parties was accompanied by a rise in popular protest in the cities. The growing number of unemployed, taxi-drivers, students and other social groups took to the streets to air their own specific grievances and their general discontent with the regime in power. Contrary to many other African countries, the trade unions refused to join and lead this popular protest as they were still state-controlled. There were several bloody clashes between the demonstrators and the forces of law and order which led to several people being killed in April 1991. By April 1991, party leaders and their followers were uniting around the claim for a national conference. This claim was inspired by the national conferences that had previously been organized in Benin and Congo during the transition to new multiparty regimes. Such conferences aimed at bringing together political, religious, business, trade union and other leaders in society, and assuming power to decide radical constitutional and other changes. In Benin the conference assumed sovereign power and ordered implementation of the changes decided, and this was what the opposition wanted in Cameroon. It wanted to force the authoritarian state to accept possibly radical constitutional changes and to expose misgovernment and corruption without fear. Such ideas, which were a challenge to the authoritarian, patrimonial state, enjoyed massive popular support.

Unsurprisingly, the Biya regime strongly opposed the organization of such a conference which was most likely to be transformed into a national tribunal. In a broadcast on 11 April 1991 Biya said that Cameroon did not need a national conference because 'democracy is already a reality'. His
CAMEROON'S POST-COLONIAL STATE REFORMS

refusal to consider a national conference gave rise to a long period of confrontation between the regime and the opposition. This confrontation was launched by a demonstration demanding a national conference at Bamenda on 11 May 1991, and the start of mass civil disobedience on 13 May 1991; there was also a general strike on 16-17 May 1991, widely followed in the western and northern provinces. From 24 June 1991 the most intense phase began, with the opposition's extension of civil disobedience to become a total shutdown in the cities, the so-called 'ghost town' campaign. This campaign involved the stoppage of all work, all trade, all traffic in the cities, except for Friday evenings and Saturdays, resulting in huge personal and public financial losses and an aggravation of the economic crisis. The government responded by not giving in.

For various reasons this ghost town campaign was not successful. It was not backed in the Beti region which remained loyal to Biya. This brought about a dangerous polarization on ethnic lines (the Beti versus the rest) which nearly led to a civil war. The state apparatus might have broken down if Biya had not had that solid regional backing. In the event it never broke down altogether. The government kept control over the forces of law and order and used them regularly to clamp down on the opposition.

The IMF and World Bank had regularly expressed their disapproval of the ghost town campaign. Greatly concerned about the adverse effect of this campaign on the national economy and SAP, they had regularly appealed to the government and opposition to arrive at a negotiated settlement. Both sides, however, ignored these appeals until October 1991 when it became evident that the ghost town campaign and, above all, the strength of the sympathetic population had exhausted themselves. Moreover, by that time there were tense conflicts among the opposition leaders about future strategy.

The offer of talks by Biya on 11 October 1991 was accepted by the opposition parties and the ghost town campaign petered out. A tripartite conference held at Yaoundé from 30 October to 17 November 1991, attended by government and opposition representatives and other prominent personalities who mediated and advised, led to agreements on 17 November 1991 which confirmed the government victory under a polite disguise. It was agreed that elections for a new National Assembly would soon be held and that, in the meantime, all protest campaigns would be called off. Some opposition parties even dropped the national conference idea. This, and the failure to arrive at a programme for change, were the main reasons why other opposition parties, like the SDF, declined to sign the agreements.

Among those satisfied with the agreements were the IMF and World Bank as well as the government of France. Biya attended a francophone state summit in Paris soon afterwards and was said to have had a good reception and approval from Mitterrand. Although some of Mitterrand's Africa policy-makers seemed to have favoured a national conference in 
Cameroon, a delegation of Cameroonian opposition leaders had failed to win support in Paris in late August 1991.

Of the major opposition parties, the SDF decided to boycott the $\mathrm{Na}$ tional Assembly elections which were held on 1 March 1992. Its Chairman, John Fru Ndi, said that the new election code, which was promulgated on 16 December 1991, was bad and that there was no guarantee of just and fair elections. Moreover, the election date was too early as most parties had not had sufficient time to organize and to prepare themselves for the coming elections. The government could afford to remain unmoved by such criticisms backed up by no more than the threat of a negative and self-defeating boycott. In the event, the elections distributed the 180 National Assembly seats among four parties only: the CPDM won 80, the UNDP 68, the UPC 18 and the Mouvement Démocratique de la République (MDR) 6.

The MDR was a party not considered important before the elections. It was headed by Dakole Daïssala, former Chairman of the city bus corporation Société des Transports Urbains en Commun du Cameroun (SOTUC), arrested as a northerner after the April 1984 coup d'état and held for six years without trial. $\mathrm{He}$ is one of the Kirdi, the ethnic minority groups in the north which were historically subordinate to the Fulbe and remained pagan or became Christian rather than Muslim (Motaze 1990). Most of the Kirdi declined to join the Fulbe-dominated UNDP and, during the elections, tended to cast their votes in favour of either the CPDM or the MDR.

For a party which had the full support of the government and its local officials, and which was the only party to field candidates in all forty-nine constituencies, the CPDM's showing was not too impressive. Eventually, it was three seats short of a majority in the Assembly, but after several weeks of discussion it agreed on a coalition with the MDR. This first coalitiongovernment in Cameroon was headed by an Anglophone from the North West Province, Simon Achidu Achu. A former Minister of Justice under Ahidjo, he is the first anglophone Cameroonian to be Prime Minister of Cameroon. Biya indeed owes them many thanks, for their following the SDF call to boycott the polls ensured the CPDM's victory.

Soon afterwards, Biya announced that presidential elections were to be held on 11 October 1992 and that he would stand again as the government candidate during these elections. During the subsequent negotiations, the opposition parties failed to unite on the selection of one common candidate. A mixture of personal and ethnic animosities impeded any agreement. Eventually, approximately thirty opposition parties decided to support the SDF candidate, John Fru Ndi. After the elections which were marked by massive fraud, Biya was declared to be the victor. He was said to have won 39.9 per cent of the votes cast, 4 per cent more than John Fru Ndi. This was far short of the almost 100 per cent he had received in each of the two previous elections in 1984 and 1988 respectively, when he was the only candidate running for the post. He only won in the South, Centre and East
Provinces (partly coinciding with the Beti area), but woefully lost in the other provinces.

After the elections, there were violent protests in Bamenda and the entire North West Province against 'Biya's theft of John Fru Ndi's victory'. Biya then imposed a state of emergency on this province for three months and John Fru Ndi was kept under military surveillance in his house at Bamenda Many political activists, journalists and students, particular Anglophones and Bamilike, were arrested and tortured. The United States, Germany and the European Common Market had denounced the fraudulent elections and the state of emergency in the North West Province and threatened to abandon their aid programmes to Cameroon until 'there was a clear advancement in the democratic process'. Particularly the United States has often expressed its disapproval of Biya's authoritarian regime and has openly supported John Fru Ndi. The critical attitude of the United States towards the regime encouraged France to display its support for Biya, who appeared to be more likely to safeguard French interests in Cameroon than the Anglophone, John Fru Ndi.

Biya's victory was a pyrrhic one. Still desperately seeking for legitimacy, because of his rejection by over 60 per cent of the population, and with the economy in complete shambles and the civil service in a state of general apathy, the President was more isolated than ever. To broaden his base of support, Biya formed a government of national unity after the elections. Some individual members of the UNDP and the moderate faction of the UPC accepted ministerial posts. The SDF, on the contrary, refused to collaborate with a government of national unity.

It would appear as if the democratization process in Cameroon has stagnated. The power of the President is still relatively unlimited; the separation between the state and CPDM party is still insufficient; censorship of the press, violation of human rights and military excesses are still commonplace.

\section{CONCLUSION}

This study has tried to demonstrate that the neoliberal project, which has been propagated by the Western donors and international financial institutions and largely supported by opposition parties, has not yet made much progress in Cameroon. This is not altogether surprising. Given the class character of the Cameroonian post-colonial state, the slow and inconsistent pace of economic liberalization was to be expected. The patrimonial logic on which the post-colonial state is built forms a clear obstacle to the institutional changes needed to carry through a transformation to marketoriented and private sector-led growth.

The rather limited political reforms introduced by the Biya regime in 1990 , especially the legalization of multipartyism, seem not to have stimulated economic liberalization but rather to have further eroded the authoritarian 
and patrimonial state's capacity and willingness to undertake economic reforms. The Biya regime rightly feared that the implementation of economic reforms, such as the dismantlement and privatization of the costly and inefficient parastatal sector and the reduction of the public service, would fuel popular discontent and augment the membership of the opposition parties. Moreover, it was obliged to proceed with the supply of privileges, in the form of rent-seeking opportunities, so as to maintain the hegemonic alliance and to stave off opposition. In addition, the regime's loss of legitimacy and the increasing political instability encouraged capital flight and deterred foreign and national private investments.

The Biya regime appears to have been quite successful in resisting the internal and external pressures to speed up the process of economic and political liberalization. As a result, the post-colonial state remains very much as it always has been. Several reasons have been given in this chapter to explain the paradox of the evident lack of commitment to economic and political reform and the remarkable survival of the authoritarian, patrimonial state during the present economic and political crisis. First, the Biya regime has continued to control the (shrinking) state resources, which enables it to buy the loyalty of the state élites and to co-opt some of the opposition leaders into the hegemonic alliance. It also continues to control the forces of law and order, which enables it to intimidate and oppress the opposition. Moreover, it continues to monopolize some pivotal mass communication media like the television, which enables it to preclude the opposition parties from presenting their leaders and programmes to the public. Second, the Biya regime has continued to enjoy the firm support of the Beti élite who feared that their privileged access to state resources would come to an end with the opposition parties' seizure of power. Third, the opposition parties seem hardly to differ from the ruling party, using similar ethno-client networks for the expansion of their power base. And, above all, their leadership is divided by personal and ethnic animosities.

And finally, the Biya regime has exploited to the full the ambivalent and inconsistent role of the Western donors and international financial institutions in the execution of the neoliberal project. The IMF and World Bank depend upon the ruling regime's continuous cooperation for the successful implementation of the SAP to such an extent that they tend to confine themselves to quiet diplomacy, except in cases of extreme violations of human rights. Conversely, they decline to negotiate with the opposition. They have even expressed their strong disapproval of certain oppositional actions, such as the 'ghost town' campaign in 1991, which they perceived as a further onslaught on the already shattered national economy and an obstruction of the SAP. Undoubtedly, in its struggle for survival, the Biya regime owes a particular debt to France. France has tried to safeguard its economic interests in Cameroon by regularly assisting the Biya regime in overcoming any internal and external oppositional action. In January 1992, it did not even hesitate to supply the Biya regime with arms for the maintenance of public order.

Of late, however, there are some indications that the Western donors and international financial institutions are losing patience with the slow and inconsistent pace of economic liberalization in Cameroon and becoming more determined to impose upon the Biya regime the tough choices it has so far avoided. In 1994, the World Bank forced the regime to lay off 20,000 civil servants and to announce the privatization of a first batch of fifteen important parastatal enterprises, notably in the transport and agroindustrial sectors.

It is most unlikely that the eventual achievement of greater political liberalization in Cameroon will enhance the prospects for any thorough economic liberalization. Political liberalization may even strengthen the patrimonial features of the Cameroonian post-colonial state. Although most opposition parties claim to champion economic liberalization, their capacity to implement the necessary economic reforms is very much open to question, since they appear to resemble closely the ruling regime in their frequent resort to patrimonial practices.

Much of the current thinking about political liberalization in Africa implies that institutional and economic change will be effected via the emergence of stronger civil societies. As a result, successful economic reforms require not only increased levels of state capacity but also higher levels of 'civil society capacity', that is, the effective and sustained organization of social interests over time. Civil society capacity, however, is still underdeveloped in Cameroon. Every organized group in Cameroonian civil society used to be co-opted or destroyed by the state, from trade unions to farmer cooperatives. Until these groups develop a certain degree of autonomy, they lack the power to call the regime to account for its policies (van de Walle 1990).

The experience in Cameroon, and elsewhere in Africa, suggests that there is no automatic linkage between political and economic liberalization. In African countries where autocratic and patrimonial regimes are still struggling for their political survival during the democratization process, economic reforms tend to be slowly and partially implemented and political reforms tend to create political instability which scares away national and international investors. Indeed, at least in the short term, there may be conflicts between the two objectives. There is thus an increasing tendency to emphasize the longer-term relationship between political and economic liberalization, as well as to view democracy as an end in itself, rather than a means to development.

\section{REFERENCES}

Azarya, V. (1978) Aristocrats Facing Change: The Fulbe in Guinea, Nigeria and Cameroon, Chicago: University of Chicago Press. 


\section{PIET KONINGS}

Bandolo, H. (1985) La flamme et la fumée, Yaoundé: SOPECAM.

Bayart, J.-F. (1979) L'Etat au Cameroun, Paris: Presses de la Fondation Nationale des Sciences Politiques.

-(1989) L'État en Afrique, Paris: Fayard.

Beckman, B. (1993) 'The liberation of civil society: Neo-liberal ideology and political theory', Review of African Political Economy 58: 20-33.

Callaghy, T. M. and Ravenhill, J. (eds) (1993) Hemmed In: Responses to Africa's Economic Decline, New York: Columbia University Press.

DeLancey, M. W. (1989) Cameroon: Dependence and Independence, Boulder/San Francisco: Westriew Press.

Derrick, J. (1992) 'Cameroon: One party, many parties and the state', Africa Insight 22, 3: 165-77.

Geschiere, P. and Konings, P. (eds) (1993) Itinéraires d'accumulation au Cameroun, Paris: Karthala.

Henry, A., Tchenk, G. H. and Guillerme-Dieumegard, Ph. (1991) Tontines et banques au Cameroun, Paris: Karthala.

Hugon, Ph. (1968) Analyse du sous-développement en Afrique noire: L'exemple de l'économie du Cameroun, Paris: Presses Universitaires de France.

Jeffries, R. (1993) 'The state, structural adjustment and good government in Africa', Journal of Commonwealth and Comparative Politics 31, 1:20-35.

Johnson, W. P. (1970) The Cameroon Federation, Princeton: Princeton University Press.

Joseph, R. A. (1977) Radical Nationalism in Cameroon: Social Origins of the UPC Rebellion, Oxford: Clarendon Press.

(1978) Gaullist Africa, Enugu: Fourth Dimension Publishers.

Jua, N. (1991) 'Cameroon: Jump-starting an economic crisis', Africa Insight 21, 1: $162-70$.

Konings, P. (1993) Labour Resistance in Cameroon, London: James Currey.

Körner, P. (1988) 'Kamerun-afrikanisches "Musterland" in der Krise', Afrika Spektrum 88, 1: 77-94.

Le Vine, V. T. (1964) The Cameroons from Mandate to Independence, Berkeley/Los Angeles: University of California Press.

Angeles: University of California Press. (1971) The Cameroon Federal Republic, Ithaca NY: Cornell University

Médard, J.-F. (1977) 'L'état sous-développé au Cameroun', L'Année Africaine, Paris: Pedone.

Mehler, A. (1993) Kamerun in der Ära Biya, Hamburg: Institut für Afrika Kunde.

Mkandawire, T. (1994) 'Adjustment, political conditionality and democratisation in Africa', in G. A. Cornia and G. K. Helleiner (eds) From Adjustment to Development in Africa: Conflict, Controversy, Convergency, Consensus? New York: St Martin's Press.

Motaze, A. (1990) Le Défi paysan en Afrique: Le laamido et le paysan dans le nord $d u$ Cameroun, Paris: L'Harmattan.

Ngayap, P. F. (1983) Cameroun: qui gouverne?, Paris: L'Harmattan.

Pelzer, R. (1994) 'Der Fall Kamerun: Erste Auswirkungen und Perspektiven der FCFA-Abwertung', Afrika Spektrum 29, 2: 207-15.

Schilder, K. (1993) 'La démocratie aux champs: Les présidentielles d'octobre 1992 au Nord-Cameroun', Politique Africaine 50: 115-22.

Takougang, J. (1993) 'The demise of Biya's New Deal in Cameroon, 1982-1992', Africa Insight 23, 2: 91-101.

Tedga, P.-J. M. (1990) Entreprises publiques, état et crise an Cameroun, Paris: L'Harmattan

Vallée, O. (1989) Le prix de l'argent CFA, Paris: Karthala.

\section{CAMEROON'S POST-COLONIAL STATE REFORMS}

Walle, N. van de (1990) 'The politics of non-reform in Cameroon', in African Governance in the 1990s: Objectives, Resources and Constraints, Atlanta, Georgia: The Carter Center of Emory University.

Warnier, J.-P. (1993) L'esprit d'entreprise au Cameroun, Paris: Karthala. 